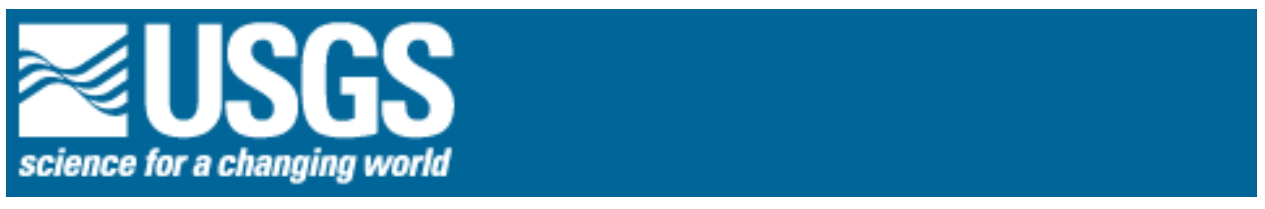

\title{
National Land Cover Dataset
}

The U.S. Geological Survey (USGS), in cooperation with the U.S. Environmental Protection Agency, has produced a land cover dataset for the conterminous United States on the basis of 1992 Landsat thematic mapper imagery and supplemental data. The National Land Cover Dataset (NLCD) is a component of the USGS Land Cover Characterization Program. The seamless NLCD contains 21 categories of land cover information suitable for a variety of State and regional applications, including landscape analysis, land management, and modeling nutrient and pesticide runoff. The NLCD is distributed by State as 30-meter resolution raster images in an Albers Equal-Area map projection.

\section{Data Classification System Key}

\section{Open Water}

12 Perennial Ice/Snow

21 Low-Intensity Residential

22 High-Intensity Residential

23 Commercial/Industrial/Transportation

31 Bare Rock/Sand/Clay

32 Quarries/Strip Mines/Gravel Pits

33 Transitional

41 Deciduous Forest

42 Evergreen Forest

43 Mixed Forest

51 Shrubland

61 Orchards/Vineyards/Other

71 Grasslands/Herbaceous

81 Pasture/Hay

82 Row Crops

83 Small Grains

84 Fallow

85 Urban/Recreational Grasses

91 Woody Wetlands

92 Emergent Herbaceous Wetlands

\section{Available Products}

State data files are available on compact disc as Geo-TIFF.

\section{Information}

An online description of the USGS Land Cover Characterization Program and the NLCD is available at edcwww.cr.usgs.gov/ programs/lccp.

For more information, contact Customer

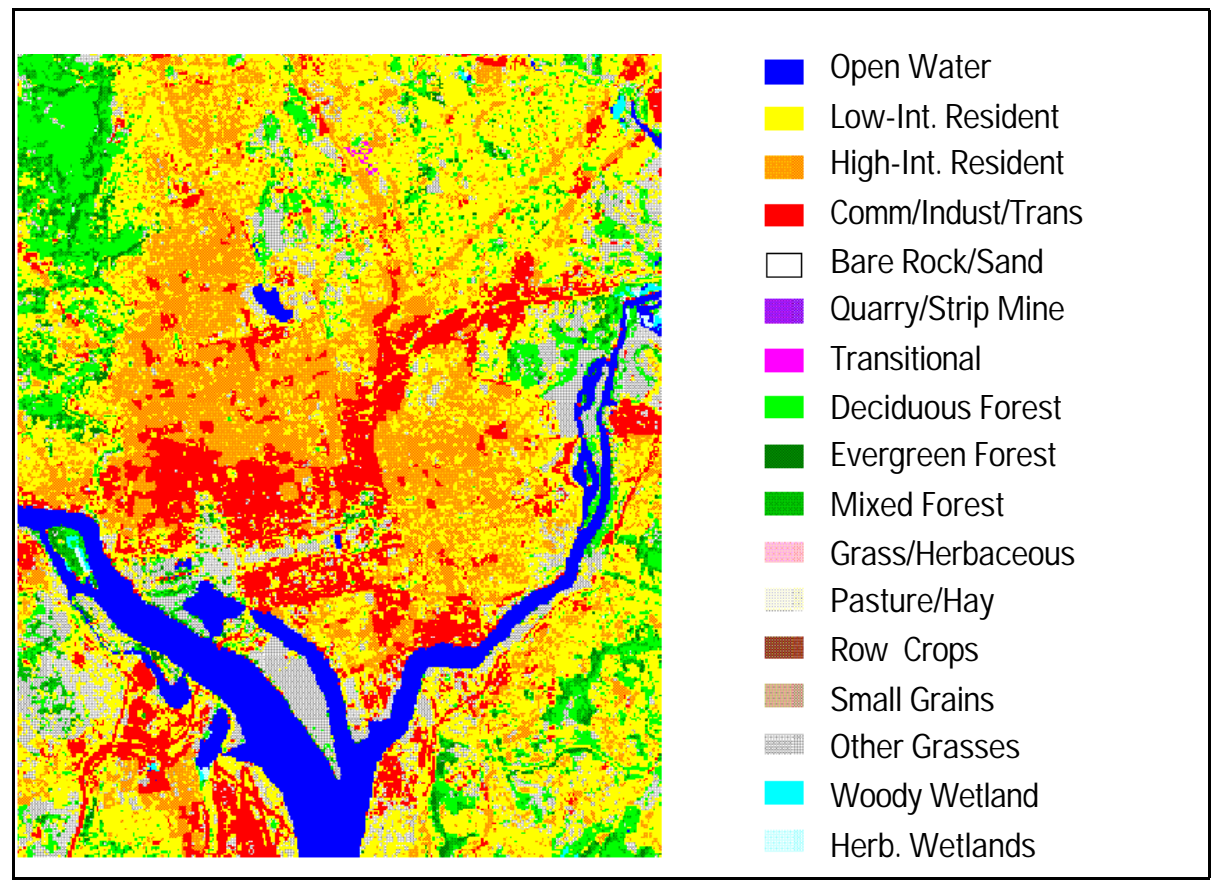

Detailed example of National Land Cover Dataset, W ashington, D.C.

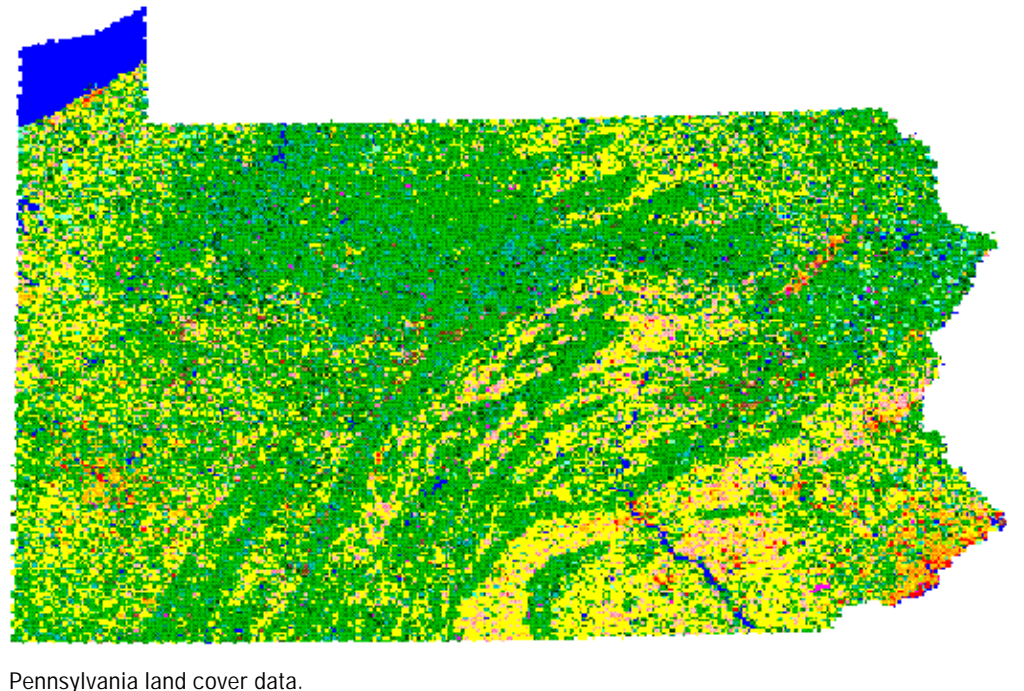

Services:

Earth Science Information Center EROS Data Center

Sioux Falls, SD 57198

Telephone: 605-594-6151

Fax: 605-594-6589

E-mail:custserv@usgs.gov

For information on these and other USGS products and services, call 1-888-ASK-
USGS, use the Ask.USGS fax service, which is available 24 hours a day at 703-648-4888, or visit the general interest publications Web site on mapping, geography, and related topics at mapping.usgs.gov/mac/isb/pubs/ pubslists/.

For additional information, visit the ask.usgs.gov Web site or the USGS home page at www.usgs.gov. 